\title{
NEPAI and African Development: Towards a New Partnership between Development Actors in Africa
}

\section{Rawia M. Tawfik *}

\begin{abstract}
The model required to drive socio-economic development in Africa, and the relationship between the state and the private sector based on that model, have sparked much controversy among African analysts. Some question the relevance of other successful models of development, such as in the liberal West or in East-Asia, to the African context. Others criticise all models of development that are "alien" to African cultures and conditions hence rejecting the NEPAD model on this basis. This paper argues that although NEPAD does not present a detailed model of the relationship between the state, the private sector and civil society in Africa, some of its theoretical underpinnings suggest a balanced framework that should prompt African scholars to search for new models that do not necessarily imitate already successful ones but respect the particularities of each African state.
\end{abstract}

\section{Resumé}

Le modèle requis pour tirer le développement socioéconomique en Afrique ainsi que le lien qui existe entre l'Etat et le secteur privé, conformément à ce modèle, ont été à l'origine d'une grande polémique au sein des analystes Africains. D'aucuns discutent sur la pertinence, pour l'Afrique, d'adopter des modèles de développement couronnés de succès, soit dans un contexte

* Department of Politics, Cairo University. 
libéral occidental, soit en Asie de l'Est. D'autres s'adonnent à la critique de tous les modèles de développement 'étrangers' aux cultures et aux réalités de l'Afrique et rejettent dans la même lancée le modèle préconisé par le NEPAD. Ce document soutient que même si le NEPAD ne fait pas une présentation détaillée du lien qui devrait exister entre l'Etat, le secteur privé et la société civile en Afrique, quelques unes de ses explications théoriques préconisent un cadre équilibré qui inciterait les experts Africains à chercher à élaborer de nouveaux modèles qui n'imiteraient forcément pas ceux déjà couronnés de succès, mais de modèles qui respecteraient plutôt les spécificités de chacun des Etats africains

\section{Introduction}

Development strategies in Africa are biproducts of a certain historical moment with its social, economic and political conditions as well as the dominant or leading development thought of that moment. While the Lagos Plan of Action was the product of a state-led and collective selfreliance mode of development, NEPAD, coming more than twenty years later, reflects the post-Washington consensus model of development. The debate within the latter model is no longer about whether the state should intervene in the development process. It is rather about the mechanisms of such intervention and the best relationship between the state, the private sector and civil society for achieving development. Nevertheless Africa is still in a need of a new development model that can provide a partnership framework between the three main development actors.

In its own theoretical framework NEPAD seeks such a model, but can NEPAD really provide an effective model of development in Africa? This paper examines that broad question by posing the following more specific research questions:

- What was the model of development aspired to by previous African development plans? Was the relative failure of such plans related to problems with the theory or with the implementation?

- Does NEPAD present a genuinely new model of development that avoids the shortcomings of previous development plans? What has NEPAD achieved in this respect in the last four years?

- To what extent can the African Peer Review Mechanism, which aims at sharing the best development practices among African countries, contribute to the development of these countries? 
Accordingly the first part of this paper briefly discusses the developmental role of the state in Africa since independence, the second part examines the main development initiatives in Africa prior to NEPAD and their contribution to addressing the African development predicament, and the third part discusses NEPAD's perspective on the partnership between development actors in Africa.

\section{State and Development in Airica: The Sacred Leviathan}

Different explanations have been presented to explain the African development crisis that has prevailed since the end of the seventies. For some the explanation is to be found in the theory of the post-colonial state. In this view the post-independence African state retains many of the features of the colonial state, especially the state's dominant role in the political and economic realms, and is characterised, as Jean Bayart argues, by the "politics of the belly", which refers to the networks of clientalist relations that control the post-colonial state (Bayart 1993). This interpretation served as a theoretical premise for structural adjustment programmes (SAPs) that aimed, as many African analysts maintain, to undermine the role of the state and had the effect of making the weak states of Africa even weaker, leading, as Bade Onimode (1995) put it, to the strategic erosion of the state in Africa. For Mkandawire and Soludo the neo-liberal theoretical premise of SAPs, which depicts the state as the source of all evils, is simplistic. Demonising local elites and seeing their policies as merely the result of agency do not reflect the actual causes of the economic predicament in Africa. Besides the SAPs did not take into consideration that the institutions needed to perform the adjustment tasks are either weak or totally absent (Mkadawire and Soludo 1999). For Tade Akin undermining the role of the state has affected its legitimacy and increased its suppressive role, leading to even greater exclusion of some social groups (Akin 1999: 79-109), while for Helmi Sharawi the retreat of the state has resulted in spreading corruption, as introducing free-market economies fuels the impulse for self-enrichment. Accordingly the institutionalisation of corruption has replaced the rule of law (Sharawi 2001: 35-38. Thus the main criticisms of the neo-liberal paradigm, as reflected in SAPs, identify the downplaying of the role of the state, the underestimating of the weaknesses of African state institutions, the social repercussions of the erosion of the role of the state and the role of free market in promoting corruption as the key factors that make this paradigm counter-productive. It will be important 
to keep these arguments in mind when considering the theoretical premises of NEPAD .

In the contrary view the state is the centre of gravity around which African development thinking should revolve despite the fact that the current model of the state in Africa cannot serve as an engine for economic development, since most African states fall prey to special interests that render it an "elitist phenomenon" (Kasongo 2003: 128). On the other hand very little has been written on the potential role of the private sector or on the prospects of public-private partnerships (PPPs). In the post-independence era this may have been justifiable, as state domination ofeconomic planning and development led to a relatively weak and small private sector. Moreover since the 1980s the highly criticised SAPs, favoring market mechanisms at the expense of the state, have led to the private sector being demonised by many African analysts and blamed for key aspects of the African economic crisis. Few have been concerned with the fact that state policies, either by not providing an encouraging environment for investment or through reliance on clientalist networks, have led to the flight of African private capital out of the continent. According to James Wolfenson, the former president of the World Bank, 37 percent of the private capital of African business is invested outside the continent compared to 3 percent in the case of Asia and 17 percent for Latin America (Wolfenson 1998: 9).

As for the role of civil society African scholars, while admitting its role in promoting development, have had many reservations about that role. For Yusuf Bangura (1999) civil society in Africa is not really "civil", that is, it is not based on inclusive participation but on narrow interests. Similarly much has been written on civil society's relationship with western donors and how this relationship affects its supposed role in promoting "good governance", as well as on the lack of coordination between civil society organisations across the continent (Beckman 1993; Abdel Rahman 2004). Little has been written on the potential development role of civil society, especially community-based organisations (CBOs) working at the grassroots, despite the fact that this role has increased due to the retreat of the state from the provision of public services since the 1980s (Chimanikire 2003).

Most alternative models of development proposed by African analysts depend on ones that have succeeded elsewhere. As Mkandawire (2001: 1) bluntly argues: 
most of the analyses about African states that have led to so much despondency about prospects of development are based on invidious comparison between African states in crisis and idealized and tendentiously characterised states elsewhere. This invidious comparison has occulted the African state, making concrete analysis of its character less important than the normative statements about what it should be. The "ought" has proved more interesting than the "is"; turning debates on the state in Africa into the most pontifical and teleological of any theme in Africa.

Various models have inspired analysts. For Kasongo, for example, Africa should adopt European-style "social democracy", a model, he argues, that will be more compatible with the collective social nature of African societies than the liberal capitalist model. On the other hand, following the success of the developmental state model in East Asia, a debate began in African development circles on how this model could be replicated in Africa.

In these debates there are different understandings of the developmental role of the state, especially with regard to the relation between the state and the private sector. A developmental state, according to Mkandawire (2001), is one whose ideology is "developmentalist". This kind of state conceives its mission as one of ensuring economic development and its elite has the capacity to establish an 'ideological hegemony' and implement economic policies effectively, something that entails the autonomy of the state from social forces and private interests (Mkandwire 2001: 2-3). Edigheji (2003) adds other elements to the definition: the promotion by the state of market-enhancing rather than market-repressing economic policies and a clear division of labour between the state and the private sector under the overall guidance of a super-ministry or state agency (state-informed public-private partnership).

Edigheji also highlights the different versions of developmental states according to developmental theorists and scholars. As he points out, while some scholars adopt a strong statist interpretation of the developmental state, emphasising the importance of the state governing the market, others prefer a model based on consensus-building and complementarity between the state and the private sector (Edigheji 2003: 3-8). Thus the debate has sometimes shifted from searching for a functional model of development in Africa to debating successful models 
of development elsewhere, without even agreement on the description of such models and the reasons behind their success.

To sum up, African scholars tend to support a leading role for the state in the development process, even while criticising the predatory, elitist and repressive features of the current African state. Some support the reinvention of the African state to make it both developmental and democratic. Some recognise that it is not only the role of the state that is decisive in the development process but also its capacity. This depends on strong and effective state institutions with autonomy from special interests that would exploit the state for self-enrichment. One needs also to admit that the state is no longer the sole development actor in African countries. Accordingly a clear division of labour between the three main development actors is needed.

\section{Development Initiatives beiore NEPAD: A Gritical Review}

If the elements of state capacity, autonomy and partnership with development actors are indeed central to African development, to what extent have these elements been addressed in African development plans from the Lagos Plan of Action up to NEPAD? A review of African development plans before NEPAD reveals that there were significant gaps in dealing with these elements. When the African development predicament emerged at the end of the seventies and the beginning of the eighties, African governments responded with the Lagos Plan of Action (LPA). As a product of its historical moment the LPA reflected the African development thought of that time, with its emphasis on collective selfreliance and state-led development. In this view the state was the leading actor and should bear the burden of elaborating the social, economic and cultural policies that enable the mobilisation of the resources and capabilities of the country. The LPA also emphasised the role of the state in the fair distribution of both development burdens and benefits. Although it did not explicitly discuss the role of the state in development, the LPA made it clear that the state was both part of the development crisis and the main agent for its resolution. The strategies that had been adopted by African states were, according to the LPA, mainly responsible for the crisis.

Although the LPA provided for African integration, it did not adequately address the crucial elements for African development discussed above, namely, capacity, autonomy and partnership. While concentrating on sectoral programmes, the Lagos plan did not adopt a detailed strategy 
for building the capacity of domestic institutions in African countries. The plan also dealt with the African development predicament as a mainly, if not purely, economic crisis; corruption and clientalism were not major concerns. Thus it was not only the lack of external support that led to the less than successful implementation of the LPA but also the internal flaws of the plan itself.

The United Nations Programme of Action for African Economic Recovery and Development (UNPAAERD) adopted by the twenty-first Ordinary Summit of the OAU in July 1985 avoided some of the LPA's shortcomings. It emphasised the central role of the state in the development process but added the need for building the capacity of state institutions to enable it to perform this role. UNPAAERD also asserted the importance of the private sector, but confined itself to stating that ' $[\mathrm{t}]$ he positive role of the private sector is also to be encouraged through well-defined and consistent policies' (Art. 1 lei). At the end of the 1980s the United Nations Economic Commission for Africa (UNECA) proposed the African Alternative Framework to Structural Adjustment Programme (AAF-SAP), one of whose main arguments was to debunk the SAPs' promotion of a minimal role for the state. It argued that privatisation was failing due to the lack of an efficient, robust private sector in most African countries and the resulting danger of domination of African economies by foreign capital. Four imperatives needed to be applied, the framework stated, to the path of adjustment: strengthening and diversifying Africa's production capacity, improving the levels and distribution of people's incomes, adjusting public expenditure to meet people's essential needs and providing institutional support for adjustment with transformation. While many African scholars celebrated AAF-SAP for its critique of SAPs and its attempt to elaborate an alternative plan based on mobilising national resources and supporting regional integration, others did not regard it as a real alternative framework and criticised it as state-centered. In response Adebayo Adedeji, then General Secretary of the UNECA and the main architect of AAF-SAP, argued that it proposed a balanced non-ideological vision that neither called for wholesale state intervention nor promoted total reliance on markets (Onimode 1995: 138-140).

AAF-SAP's attempt to develop an alternative framework to SAPs was complemented by the Arusha Conference on Popular Participation in Development in 1990, which adopted the African Charter for Popular Participation in Development and Transformation. The charter introduced 
the idea of partnership between the state and civil society for promoting development based on popular participation. According to the charter civil society organisations can and should mobilise the African masses to effectively participate in negotiating and debating development policies, while also serve as an oversight tool to review the extent to which the state is committed to implementing its development policies (Economic Commission for Africa 1990). The charter proposed establishing a dialogue forum between state and civil society organisations in every African country to institutionalise this partnership (Economic Commission for Africa 1990). Given the ambitious populist strategy of the African charter, it was little wonder that it was enthusiastically welcomed by African civil society organisations. However the charter fatally lacked an implementation mechanism, and as a result this idealistic plan went nowhere.

To sum up, the African development plans of the eighties and nineties concentrated on establishing an alternative development strategy to SAPs, a strategy in which the state would play a central role in the development process. Some of these plans realised that there had to be reform of public management systems and capacity building for state institutions, while others relied on a partnership between the state and civil society to achieve a people-centered model of development. However these plans were sceptical about the role of the private sector; while admitting a private-sector role theoretically and claiming to want to encourage this role, no action plans were adopted to achieve the integration of the private sector in African development strategies.

\section{NEPAD and Airican Development: Partnership and Division of Labour}

The ideological orientation of NEPAD, and its perspective on the role of the state in the development process, cannot be understood without considering the shift in thinking that has taken place in the neo-liberal institutions, especially the World Bank, in recent years. During the 1970s and 1980 s these institutions demonized state intervention in the economy, but by the late 1990s they began to admit that the state had a role to play and that its capacity to do so needed to be enhanced. This change came from inside the neo-liberal institutions themselves. At the World Bank, Joseph Stiglitz led the move away from the "Washington consensus", with its rejection of state intervention, when he criticised neo-liberal theory for not recognising the important role of the state in enhanc- 
ing human capital and promoting development. What Stiglitz proposed was a mode of partnership between the state, the private sector and civil society. For him an effective development strategy 'must include components aimed at developing the private sector, the state (the public sector), the community, the family, and the individual' (Stiglitz 1998:24; see also Onis and Senses 2003).

This self-critique was a result of various factors, but the most prominent was the failure of SAPs in Africa compared to the "economic miracle" that took place during the same period in several East-Asian countries in which the state played an important role. A significant landmark in the changing neo-liberal thinking was the 1997 World Development Report, (World Bank 1997: 6) which noted that the most successful modern development models were ones in which the state balanced the role of markets in order to correct market failures and maintain social justice:

Reducing or diluting the state's role cannot be the end of the reform story. Even with more selectivity and greater reliance on the citizenry and on private firms, meeting a broad range of collective needs more effectively will still mean making the state's central institutions work better. For human welfare to be advanced, the state's capability defined as the ability to undertake and promote collective actions efficiently - must be increased. This basic message translates into a two-part strategy to make every state a more credible, effective partner in its country's development: Matching the state's role to its capability and raising state capability by reinvigorating public institutions. This means designing effective rules and restraints to check arbitrary state actions and combat entrenched corruption. It means subjecting state institutions to greater competition to increase their efficiency. It means increasing the performance of state institutions, improving pay and incentives. And it means making the state more responsive to people's needs, bringing government closer to the people through broader participation and decentralization. Thus, the Report not only directs attention to refocusing the state's role, but also shows how countries might begin a process of rebuilding the state's capability.

A similar orientation was proposed by the Organisation for Economic Cooperation and Development (OECD), which has promoted the logic of public-private partnerships. This requires trust-building between the state and the private sector so that their relations can be based on complementarity instead of competition, with the aim of building an institutional framework for the development process that does not hinder 
the role of the market and at the same time does not ignore the social aspects of development (OECD 2003).

However these examples do not necessarily mean that a dramatic shift is underway in neo-liberal theory. As Erma Mawdsley and Jonathan Rigg concluded after reviewing World Development Reports from the late 1970s through to 2002, 'the substantial shift towards more participatory language and approaches, while welcome, is still underpinned by utilitarian values, in which a depoliticized version of "empowerment" is valued primarily for its contribution to the main goal of economic growth' (Mawdsley and Rigg 2003). Nevertheless the emerging post-Washington consensus indicates the demise of the statemarket dichotomy and the rise of a debate that is not concerned with state intervention per se but with the form and extent of that intervention and with building the capacity of the state to match its development tasks .

Returning to NEPAD, many analysts and commentators share the view that its ideological orientation is based on the neo-liberal mode of development (Tandon 2002; Arthur 2003). However this orientation reflects the post-Washinton consensus; it does not explicitly aim at eroding the role of the state, as claimed by some African analysts, but instead advocates a partnership between state, market and civil society, with the main emphasis on the first two actors. NEPAD's language concerning the roles of the state and the market represents a compromise between the language of the Millennium Partnership for the African Recovery Programme (MAP), which emphasised the role of the state and the importance of building the capacity of its institutions (Department of Trade and Industry 2001) and that of UNECA's Compact for African Recovery, which praised the role of the private sector and advocated a healthy private sector as a solution for Africa's economic predicament (Economic Commission for Africa 2001). These two documents, with the addition of the OMEGA plan, were the main sources of NEPAD's thinking.

The compromise language of NEPAD is clear throughout the document. While it praises the neo-liberal development model and argues that the increasing commitment of African states to market-oriented economies is a sign of hope and progress (NEPAD 2001: par. 7), it also notes that the role and capacity of the state are matters of concern. According to the document, "the weak state remains a major constraint on sustainable development in a number of countries. Indeed, one of 
Africa's major challenges is to strengthen the capacity to govern and to develop long-term policies' (NEPAD 2001: par. 23). Accordingly capacity-building for state institutions is given a high priority, at least theoretically, in the initiative:

State capacity-building is a critical aspect of creating conditions for development. The state has a major role to play in promoting economic growth and development, and in implementing poverty reduction programmes. However the reality is that many governments lack the capacity to fulfill this role. As a consequence many countries lack the necessary policy and regulatory frameworks for private sector-led growth. They also lack the capacity to implement programmes, even when funding is available. It is for this reason that targeted capacity-building should be given high priority. Programmes in every area should be preceded by an assessment of capacity, followed by the provision of appropriate support (NEPAD 2001: par 86-87).

In line with this some practical steps have been taken to build the capacity of African institutions, one of which was the fourth Pan-African Conference of Ministers of Public Service, held in May 2003, which adopted a Programme on Governance and Public Administration aimed at ensuring that African governments have the capacity to govern effectively and deliver public goods (NEPAD 2002: 73). It is also now an official objective of NEPAD to establish a technical unit in each African country, administered by African experts rather than experts from international financial institutions, to help build institutional capacity in all state institutions .

The question remains, what will be the actual impact of such initiatives on the capacity of African institutions? Is NEPAD already beginning to lose momentum and interest among African analysts and, more importantly, among the African people? While hundreds of papers have been written on NEPAD, very few are concerned with the implementation steps needed to esnure state capacity-building. There is a danger that NEPAD may gradually drift into being little more than a series of routine meetings and celebrative gatherings that accomplish little and do not attract the attention of many.

Regarding the issue of state-private sector partnership, some practical steps have been taken. NEPAD is clear in urging 'dialogue between the government and the private sector to develop a shared vision of economic development strategy and remove constraints on private sector development' (NEPAD 2001: par. 164). In this spirit the NEPAD 
Business Group (NBG) for Africa was created on the margins of the International Conference on Financing for Development in March 2002 in Monterrey, Mexico. The NBG has undertaken a number of initiatives that are currently at different stages of implementation, including the Investment Climate Facility for Africa, the development of a Small Medium Micro Enterprises (SMME) Strategy for Africa and the Seal of Good Corporate Governance (NEPAD 2003/2004: 40-41).

Other national NEPAD business initiatives have been formed. In South Africa the NEPAD Business Group has developed four "covenants", namely, Corporate Governance, Corporate Social Responsibility, Elimination of Corruption and Bribery and Accounting and Auditing Practices (NEPAD 2002: 67). NBGs in Lesotho, Nigeria and Kenya have recently followed suit (NEPAD 2003/2004: 41).

The Role of Civil Society in Public-Private Partnerships

While the partnership between the state and the private sector, and the initiatives taken to promote the role of the latter, have received a lot of attention, both rhetorically and practically, in the last four years, the question of the role of civil society has not attracted the same level of concern. Those documents that discuss the role of civil society tend to put emphasis on the integration of the sector in the NEPAD process as a channel for popular participation rather than on civil society's potential as a partner in development. Thus, as a way of approaching civil society activists and addressing criticism over the lack of popular participation, the NEPAD Secretariat has held a number of conferences to promote the involvement of community-based organisations (CBOs) in NEPAD implementation. However true partnership between the state and civil society needs to establish a dialogue between the two actors for discussing development policies and priorities and specifying the developmental role that civil society, especially CBOs, can play in meeting the needs of local communities.

Some partial initiatives have been taken to address this issue. One example is the cooperation between the NEPAD Secretariat and the International Fund for Agriculture Development to support to promote the participation of farmers' associations in policy formulation for increased productivity and enhanced market access. Nevertheless NEPAD's vision in regard to civil society participation in development remains less ambitious than previous initiatives, especially those related to the African Charter for Popular participation in Development. 
The African Peer Review Mechanism and the Sharing of Best Development Practices

The African Peer Review Mechanism (APRM) has the potential to be an effective mechanism for sharing best practices in the relationship between government, business and civil society. However the debate over the APRM has so far focused on issues such as sovereignty, African solidarity vs. peer pressure to promote good governance, punitive vs. non-punitive actions in dealing with non-compliance and big states vs. weak states (Cilliers 2002, 2003; Akokpari 2003; Tawfik and Kajee 2005). Little attention has been given to the potential of the APRM in highlighting the laws, institutions and practices that need to be reformed to develop a better climate for both public-private partnerships (Farlam 2005), although a central connotation of "peer review", as derived from the OECD, is the sharing of best practices.

It is against this background that the South African Institute of International Affairs (SAIIA) conducted a study on public-private partnerships to assess some African experiences in that regard. Their assessment shows that the most successful partnerships have been characterised by thorough planning, good communication, strong commitment from both parties and effective monitoring, regulation and enforcement by government. The study also shows that governments need appropriate legal and regulatory frameworks to build capacity at various levels to plan, draft, implement and monitor successful partnerships. However it was noted that no single judgment can be made on public-private partnerships; under the right conditions, and in the right sectors, PPPs can offer value for money to governments and good opportunities for investors, but governments need to undertake thorough feasibility studies, develop appropriate and rigorous regulatory frameworks, tackle corruption and demonstrate strong political commitment (Farlam 2005: 43-65).

\section{Conclusion}

Towards a New Partnership between Development Actors in Africa NEPAD, like previous African development initiatives, has its shortcomings, but it also opens up new opportunities for creating a balanced relationship between the state and the market, promoting the capacity of state and civil society institutions and increasing the autonomy of the state by combating corruption and curbing the domination of special 
interests. On the other hand the initiative depends heavily on foreign capital for its implementation, and it does not say how it will match people-centered development with private sector-led growth (Anangwe 2002). While some African scholars strive to defend the role of the state in Africa against the market fundamentalism of the "Washington-consensus" paradigm, others have recognised that the way out of the African economic predicament is to be found in some form of market-friendly state interventionism (Kamdiza, Maltosa and Mwanza 2004). A development paradigm that depends only on the state only is not adequate for socio-economic development, but depending totally on the market cannot maintain a fair distribution of resources or help fight poverty. One can also argue that what Africa needs is not just a market-friendly state interventionism but also a society-friendly private sector. Balancing the two models requires governments to fight corruption, ensure transparency and develop technical expertise to negotiate the terms of cooperation with the private sector and the private sector to act with social responsibility and play its role in African renewal. In the light of this equation there is no contradiction between the traits of an active developmental state, namely capacity and autonomy as underlined by Mkandawire, and partnership between the state and the private sector.

Achieving this balance will not be an easy task. For much of the last half-century mistrust has characterised the relationship between the state and the private sector and between the private sector and the society. NEPAD is not a complete answer to this problem, as it does not offer a comprehensive, detailed paradigm that benefits from the role of the private sector, takes the social aspects of development into consideration and ensures international support. However some theoretical aspects of the initiative can be elaborated to form the basis of such a paradigm. While NEPAD emphasises the role of the private sector, it does not ignore the need to build state capacity. The challenge remains one of implementation, especially at a time when NEPAD may have began to lose momentum. African scholars should move to the next step by specifying what NEPAD needs to do and how the initiative can be applied in every African state . 


\section{Reierences}

Abdel Rahman, H., 2001, 'The New African Initiative: Challenges of Poverty and Aspirations of Renaissance', Al-Ahram, 17 November.

Akin, T., 2001, Globalization and Social Policy in Africa, Cairo: Center for ArabAfrican Studies.

Akokpari, J., 2003, 'NEPAD's African Peer Review Mechanism: Prospects and Challenges of Implementation', OSSREA Newsletter, Vol. 21, No. 3.

Anangwe, A., 2002, 'State and Development: Relying on Foreign Capital subverts Africa's Development Agenda', Third World Network.

Arthur, K., 2003, 'NEPAD and African Development: The Musings of an Academic Pessimist', paper presented at the 14th Biennial Congress of the African Association of Political Science (AAPS), Durban.

Bangura, Y., 1999, 'New directions in State Reform: Implications for Civil Society in Africa', UNRISD Discussion Paper No. 113, Geneva: United Nations Research Institute for Social Development.

Bayart, J. F., 1993, The State in Africa: The Politics of the Belly, London: Longman.

Beckman, B., 1993, 'The Liberation of Civil Society: Neo-Liberal Ideology and Political Theory', Review of African Political Economy, No. 38.

Chimanikire, D., 2003, 'The Role of NGOs in African Economic Development', in A. A. Jalloh, ed., The Challenges of Globalization to Democratic Governance in Africa: What Role for Civil Society and Other Stakeholders?, Addis Ababa: Development Policy Management Forum (DPMF).

Cilliers, J., 2002, 'NEPAD’s Peer Review Mechanism', ISS papers No. 64, Pretoria: Institute for Security Studies.

Cilliers, J., 2003, 'Peace and Security through Good Governance: A Guide to the NEPAD Peer Review Mechanism', ISS papers No. 70, Pretoria: Institute for Security Studies.

Department of Trade and Industry, 2001, Millennium Partnership for the African Recovery (MAP), Pretoria: Ministry of Trade and Industry.

Economic Commission for Africa, 1990, African Charter for Popular Participation in Development and Transformation, New York: United Nations.

Economic Commission for Africa, 2001, Compact for African Recovery, Addis Ababa: United Nations.

Edigheji, O., 2003, 'The African State and Socio-Economic Development: An Institutional Perspective', paper presented at the workshop on Africa: Politics and Economy, National Council of Provinces, Cape Town.

Farlam, P., 2005, 'Working Together: Assessing Public-Private Partnerships in Africa', NEPAD Policy Focus Report No. 2.

Gelb, S., 2002, 'NEPAD: Opportunities and Challenges', in R. Gibb, T. Hughes, G. Mills and T. Vaahtoranta, eds., Charting a New Course: Globalization, African Recovery and the New African Initiative, Johannesburg: South African Institute of International Affairs.

Kamdiza, R., Matlosa, K. and Mwanza, A., 2004, "The Role of the State in Development in the SADC Region: Does NEPAD Provide a New Paradigm', Harare: SAPES. 
Kasongo, T. L., 2003, 'Reinventing the State as a Leading Development Agent in Africa under Globalization', African Journal of Political Science, No. 4.

Mawdsley, E. and Rigg, J., 2003, 'The World Development Reports: Continuity and Change in Development Orthodoxies', Progress in Development Studies, Vol. 3, No. 2.

Mkandawire, T., 2001, 'Thinking about Developmental States in Africa', Cambridge Journal of Economics, Vol. 25, 289-313.

Mkandawire, T. and Soludo, C., eds., 1999, African Voices on Structural Adjustment, Dakar: Codesria.

NEPAD Secretariat, 2001, The New Partnership for Africa's Development. Abuja: NEPAD.

NEPAD Secretariat, 2001, NEPAD Annual Report 2001, Midrand: NEPAD.

NEPAD Secretariat, 2002, NEPAD Annual Report 2002, Midrand: NEPAD.

NEPAD Secretariat, 2004, NEPAD Annual Report 2003/2004, Midrand: NEPAD.

Onimode, B., 1995, African Alternative to Structural Adjustment Programs, Cairo: Egyptian General Book Association.

Onis, Z. and Senses, F., 2003, 'Rethinking the Emerging Post-Washington Consensus: A Critical Appraisal', ERC Working Paper No. 03/09, Ankara: Economic Research Center.

OECD, 2003, Globalization and Governance : Main results of the OECD Development Center's Programme of work , Paris :Organisation for Economic Cooperation and Development.

Sharawi, H., 2001, Africa at the turn of the Century, Cairo: Center of Arab-African Studies.

Stiglitz, J. E., 1998, ‘Towards a New Paradigm for Development: Strategies, Policies and Processes', Prebisch Lecture, Geneva: UNCTAD.

Tandon, Y., 2002, 'NEPAD = SAP+GATs+DSB', Southern and Eastern African Trade, Information and Negotiations Initiative (SEATINA) Bulletin. No. 5.4.

Tawfik, R. and Kajee, A., 2005, 'NEPAD and APRM: Can They Deliver on Good Governance and Development in Africa', paper presented at the $15^{\text {th }}$ AAPS Biennial Conference, Cairo.

Wolfenson, J. D., 1998, 'Africa's Moment', address to UNECA, Addis Ababa.

World Bank, 1997, World Development Report 1997: The State in a Changing World, Washington: World Bank. 